International Journal of Health Sciences
Available online at www.sciencescholar.us
Vol. 5 No. 3, December 2021, pages: 232-243
e-ISSN: 2550-696X, p-ISSN: 2550-6978
https://doi.org/10.53730/ijhs.v5n3.1485

\title{
The Impact of the Pandemic on Moral Panics in Society
}

Svetlana Tolmacheva a , Alexander Tkachev b, Maxim Shamshin c
Manuscript submitted: 18 May 2021, Manuscript revised: 09 August 2021, Accepted for publication: 01 September 2021
The relevance of studying the impact of a pandemic on society is determined
not only by medical problems but also by social. The main purpose of the paper
is to study the consequences of the pandemic in modern society with its
information, cognitive-innovative, and hyperreal security. The article examines
the phenomenon of the pandemic, its impact as a global threat, and danger in
micro-, meso-, and macrosocial structures and organizations, in state and
international institutions. The pandemic becomes both a process of social
freezing in the broadest sense (in the sense of any connection between people),
and in the social, political, economic, and cultural context. The purpose of the
study is to identify the most important factors affecting the psychological and
somatic health of a person in the conditions of COVID-19. The paper presents a
review of Russian and foreign studies of the psychological impact of the
epidemic. The problem of the social impact of the pandemic as a global and
massive threat to human relations in the information and digital world is a new
phenomenon in the sociocultural space, as fear multiplies and repeats, and
panic is intensified by simulations and fantasies, sometimes even more than
real processes.

International Journal of Health Sciences (C) 2021.

This is an open access article under the CC BY-NC-ND license (https://creativecommons.org/licenses/by-nc-nd/4.0/).

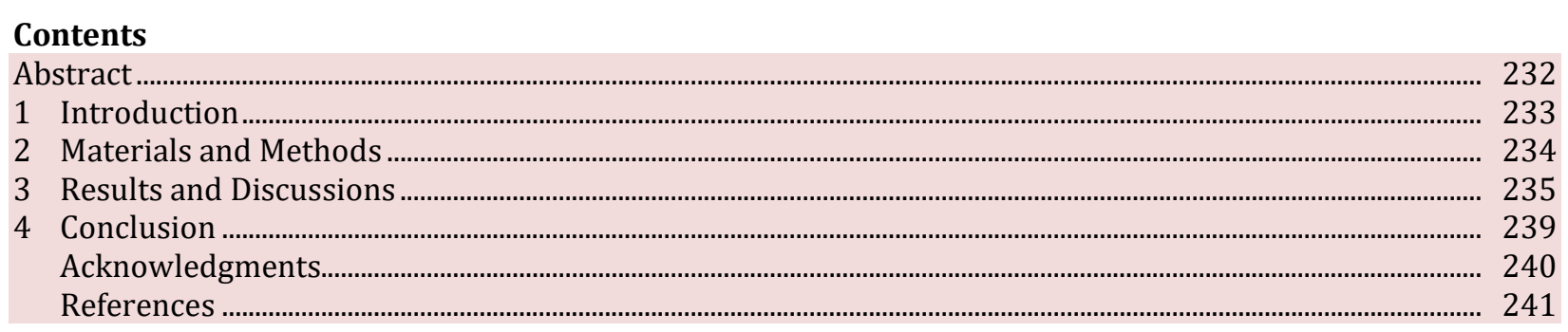

a Industrial University of Tyumen, Tyumen, Russian Federation

b Industrial University of Tyumen, Tyumen, Russian Federation

c Industrial University of Tyumen, Tyumen, Russian Federation 


\section{Introduction}

Pandemics have plagued civilizations throughout human history, with the first known epidemic occurring in 430 B.C. Many of these epidemics had a profound impact on human society, from the deaths of large parts of the world's population to encouraging people to think about their lives. COVID-19 has degraded all antivirus

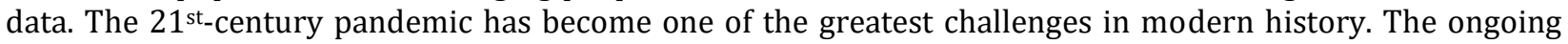
outbreak of the new coronavirus has proven the vulnerability of society to acute outbreaks. In 2020 , the dangerous disease led to the long-term introduction of quarantine and isolation regimes in more than 200 countries around the world. Approximately 2.6 billion people - a third of the world's population - live under some form of ban or quarantine (Van Hoof, 2020). The new coronavirus infection is still spreading around the world. In this situation, it is important to analyze new psychological problems and find the best solution to overcome the tense situation of the pandemic through personal and global social networks. The health and resilience of each individual is an integral part of the well-being of society, which in turn affects our thinking, emotions, actions, ability to withstand stress, and decision-making in times of crisis (Vinarchuk et al., 2021; Makovetska, 2020).

Psychological health is causally determined by the subjective view of the human world, his inner world, and individual personality traits. In other words, what matters is not the events themselves, but how they are presented to a person in his subjective worldview. During a pandemic, psychological health, human resilience, and related components can serve as key resources for maintaining physical health. Many Russian and foreign psychologists now refer to the theory of resistance and urge people to remain calm and constantly experience the problems of the pandemic (Brooks et al., 2020). Therefore, much attention is being paid to mental health, and especially to the study of practical strategies for dealing with the stress caused by the pandemic. Modern researchers of resilience describe it not as just a psychological resource of a person, but also as part of a special personality structure "resilience", consisting of three positions: commitment (involvement, responsibility), control, and risk (challenge). A resilient person sees potentially stressful events as meaningful and interesting (inclusion), imagines that they can change them (control), and uses the changes as an opportunity to develop risk-taking (Maddi \& Khoshaba, 1994; Honcharenko \& Polianychko, 2020; Bocharova, 2018).

In the case of a COVID-19 pandemic, the risk is important (Ozhegov \& Shvedova, 2018). This helps a person to remain open to the environment, society, and possible loneliness in a psychologically comfortable social environment. This must be reflected in a person's belief that everything that happens to him contributes to his development through knowledge gained from experience, both positive and negative. At the same time, the authors see a positive role as an obstacle to the development of sustainability - constructive frustration. Even the encounter with death can be an incentive for personal development and the acquisition of life philosophy. In case of trauma, the person who resists stress usually believes that he has the opportunity to extract both positive and negative experiences from his own experience, that the person can always find a new way to find the truth, the significance of impending events. According to the representative of humanistic psychology K. V. Tartu, stress makes people focus on what is happening here and now, diverting energy from unnecessary illusions, bringing people closer to reality, and making them feel more alive, which corresponds to the philosophy of Mamardashvili (1968), and Gudzhiyev (2012).

New meanings and new problems with the spread of fear, panic, changes in the system of social dependence under the influence of the pandemic determine the novelty of the study. The novelty is reflected in the use of sociology at different levels of theoretical concepts and socio-philosophical perception of the phenomenon by identifying pandemic trends in the social dimension, i.e. in microsociology, individual goals of referential relations and interactions will be adopted, mesosociology considers and studies the measurement of social behavior and activity, macro sociology, global processes in groups, communities, institutions, and organizations (Hussin et al., 2021; Ningsih et al., 2021). The subject of the study was the impact of the pandemic phenomenon as a global threat and danger to micro-, medium, and macro-social structures and organizations in large government and international institutions. The theoretical basis of the work is a structural-functional, constructivist, effective approach. Social action theory has played an important role in

Tolmacheva, S., Tkachev, A., \& Shamshin, M. (2021). The impact of the pandemic on moral panics in society. International Journal of Health Sciences, 5(3), 232-243. https://doi.org/10.53730/ijhs.v5n3.1485 
identifying the social changes caused by moral panic. Moral panic as a factor of social change is studied quantitatively and qualitatively. The method of work includes the collection (content analysis, semistructured interviews with experts, analysis of secondary data, statistical data), processing, and analysis of empirical data. The data collection and analysis procedure was conducted by the principles of sociological research.

Resilience is a concept of existential psychology, introduced by Maddi (2017). It is based on earlier categories of philosophical boldness by Tillikh \& Sedakova (1995), and the theological faith of Kierkegaard (2010). S. Maddi sees resilience as one of the ways to overcome the ontological anxiety associated with thinking or making decisions in favor of the future (Maddi \& Khoshaba, 1994). This human ability is an important part of the psychological structure of the individual, which relieves the effects of stress, ontological anxiety, and helps maintain health. As for the second element of the moral panic concept, panic etymologically comes from the Greek word "terror", which means incomprehensible horror. F.A. Brockhaus and I.A. Efron note that the name of the ancient Greek god Pan became Latin, which caused such an inexplicable fear, depriving prisoners of the opportunity to avoid precautions and threats (Arseniev \& Petrushevsky, 1897). Ozhegov \& Shvedova (2018), offers the following interpretation of this term: panic is an extreme fear, uncontrolled, immediately covering. Panic is conventionally studied in psychological science. American Psychoanalytic Association (2018), psychoanalytic terms and concepts define panic as the highest measure of anxiety. As followers of Freud's theory of anxiety, they conclude that when high intensity persists, anxiety is not taken into account, leading to temporary functional disorganization of the individual. This condition is called panic or trauma. Panic is considered a reflection of the early stages of development with a strong sense of helplessness and the global reaction of the 20th century. The psychological approach captures the unconsciousness of actions, the affected behavior of individuals as a result of panic.

\section{Materials and Methods}

The study uses the historical and psychological method, which allowed analyzing the impact of the pandemic on the psychological state and behavior of people at different stages of the epidemic, to generalize the studied material and draw conclusions. Historical and psychological research refers to the interdisciplinary interaction of two social and human sciences: history and psychology. History studies the past of humanity, and psychology studies the psyche and mental activity of a person. Both sciences originated a long time ago and successfully developed independently of each other (Loades et al., 2020; van Dyck et al., 2020). Each of them has its traditions, experience, methodology, and a variety of innate knowledge. On March 11, 2020, the World Health Organisation announced the COVID-19 coronavirus infection caused by the SARS-CoV-2 pathogen, a pandemic warning of psychological crisis and other severe psychosocial disorders. Human psychological problems related to COVID-19 are of interest to scientific psychologists and psychiatrists. The number of studies is still small - as of July 13, 2020, about 140 scientific papers were published in the Department of Science. By December 2020, more than 45,000 articles, including those by scientists from the United States, Canada, the United Kingdom, Germany, and Asia, were published in PsyArXiv.com press releases alone. There are much fewer such works in Russia - as of December 10, 2020, 7,078 scientific papers were distributed on the eLibrary portal for the query "Coronavirus" and "COVID-19". It is important that in addition to studying the psychological consequences of the pandemic for the development of all mankind, observations were made based on the subjective personal abilities and resources of people, their search for ways to cope with stress, tragedy, and fear, and complete insecurity (Shatska, 2021; Chernychko \& Ihnatyshyn, 2020).

Following the pandemic, the dependence on the growth of social depression was identified by the COVID19 coronavirus pandemic, a sociological study was conducted using an online survey. In particular, observations were carried out aimed at finding the ways to cope with a situation of stress, tragedy, fear, and complete uncertainty - in Italy, for example, the use of humor and optimism towards pandemic and isolation was investigated. Current psychologists at the University of Sheffield in England, led by Professor R. Bentall, continue to study the impact of the COVID-19 virus after subsequent quarantine on the psychological and social characteristics of human behavior from the point of view of epidemic psychology. Particularly significant psychological factors help some people cope with the crisis more comfortably than others 
(Fedosenko, 2020). At the same time, American researchers are testing the hypothesis of the impact of horror, disaster films, and epidemics on the psychological resilience of people during the COVID-19. It turned out that the respondents who preferred thrillers experienced less psychological stress and greater readiness for a stressful situation due to the coronavirus. From the scientists' point of view, this can be explained by the fact that this group of people experienced a fear of watching movies and defeating them in the real world of COVID-19 (Taylor, 2019). Home researchers alternately point to an important factor of infodemia, which has a double impact on the psychological state of people during isolation: as a useful strategy to overcome the difficult situation of the pandemic and as a negative factor in the development of anxiety and refusal of vaccination (Goghari et al., 2020). An important self-helping resource is the ability to communicate with nature to restore the mind during modern crises (Zanon et al., 2020; Cherepania \& Rusyn, 2018).

Over the centuries, humanity has developed reflexes in the face of impending infection. As a result, people have developed several unconscious psychological reactions, which M. Schaller called the behavioral immune system (Schaller et al., 2015; Prus, 2021). It is the first defense line against the impact of potential pathogens. The human mind is prone to irrational fears if the pandemic remains. For example, the fear that the infection is caused by food, or that pets are the carriers of a new virus, etc. At the same time, the experiments of M. Schaller have shown that people who feel threatened by a dangerous disease often have more respect for the safety instructions that are offered to them. However, there are exceptions to all the rules. The lack of effective deployment of advanced pandemic defense has led to the most significant global changes in mass consciousness: spontaneous behavior in the presence of a potentially fatal condition, the creation of personalized products at random extraordinary costs, discreditation of authorities, and the transition to a mythological and religious worldview, calming the emotions of insecurity through ritual behavior, which often means psychosis; focusing on information flows that reproduce the threat and emergence of excess weight, tension, fear, and panic behavior; a sublimation of fear into a substitute object (using the terminology of Konrad Lorenz) - in the absence of a solution to the problem and the ability to influence the cause, a substitute object of aggression is created, releasing the energy of tension in hostile friendly relations (Kuzmenko et al., 2021).

The virus that caused the panic creates new social media habits and destroys some of the old ones. For example, the social and physical distance between people increases, because it is reasoned by the hygiene. In communication between people, new topics appear (plastic curtains in pharmacies, homemade bactericidal substances). People are discouraged. In other words, the ways of contact and communication are limited and cause fear and distrust. Transport and shopping centers are no exception. The only exception is the inner circle, the family circle, but it was the dependence on the family circle that led to the affection of the masses in Italy. This is a fundamental violation of social model relationships, which creates a new element of tension and panic.

\section{Results and Discussions}

The results of this study may not be entirely related to the current situation, as the coronavirus pandemic has led to global isolation for the first time in history. Scientists have not yet studied this revolutionary historical period and its impact on the human psyche and health. However, psychologists are already noticing an increase in anxiety, suicidal tendencies, domestic violence, as well as the onset of panic attacks and emotional dysregulation. Especially serious psychological consequences are predicted for people who have recovered from COVID-19. At the same time, quarantine has become a serious test, not for everyone, some have found many advantages in the current situation and, on the contrary, do not want to return to the previous lifestyle. According to the theory of Selye (1960), and Douglas' theory of perceived danger, public health crises cause people to have negative emotions and even affect cognitive abilities. Negative emotions serve to protect people from potential infections when it comes to physical health. However, their prolonged exposure can reduce immune function and disrupt the physiological functions of the human body (Brewer, 2019).

Studies of the psychological effects of epidemics over the past 20 years show that such events in their lives negatively affect people's consciousness, as they deviate from common social norms; warning or temporary detention; the suspension from normal daily activities (such as going to the office or playing sports); economic damage. And with those who have worked hard and cannot isolate themselves, anything can happen. Forced

Tolmacheva, S., Tkachev, A., \& Shamshin, M. (2021). The impact of the pandemic on moral panics in society. International Journal of Health Sciences, 5(3), 232-243. https://doi.org/10.53730/ijhs.v5n3.1485 
isolation for more than 10 days has been shown to lead to depression (Zanon et al., 2020). At the same time, prolonged isolation destroys a person's health not only morally, but also physically. An increased risk of loneliness has also been shown to increase the risk of suicide. It does not matter whether a person is forced to endure isolation or it is voluntarily: suicidal thoughts are more common in lonely people who are depressed. Up to $70 \%$ of them mention suicidal thoughts and 15\% commit suicide. Therefore, the problem of suicide is a problem of loneliness and depression (Ivanova et al., 2016). Psychological reactions caused by COVID-19, which are less of a danger to a particular person than a stressful atmosphere, increase the risk of suicide. It is most common among people who have experienced physical abuse, including child pornography, bullying, and more (Van Hoof, 2020). Emotional isolation, depression, sadness, anxiety, distress, or financial stress are known to increase the risk of suicide. Most likely, these feelings can be experienced during a crisis like a pandemic. At the same time, it has been shown that not everyone has or suffers from serious psychological problems in an extraordinary situation. A significant proportion of people (more than 30\%) show resilience, that is, the ability to pass complex tests relatively easily (Li et al., 2020). The ideals of moral fear emergence force to think about these events from a multidimensional point of view, so the typology was created based on methodology, the theory of true social construction, and the theory of planning (Table 1).

Table 1

The structural components of the phenomena of actual moral panic (AMP) and panic social mood (PSM)

\begin{tabular}{|c|c|c|}
\hline & AMP & PSM \\
\hline Purpose & \multirow{2}{*}{\multicolumn{2}{|c|}{$\begin{array}{l}\text { constructing a social conflict } \\
\text { media, sociology }\end{array}$}} \\
\hline Fields & & \\
\hline Fielas & religions, cultures & economics, politics \\
\hline Capital & \multicolumn{2}{|l|}{ symbolic, economic, social } \\
\hline Resources & \multicolumn{2}{|c|}{$\begin{array}{l}\text { prestige, maintaining reputation, attracting new funds, strengthening } \\
\text { positions on the social ladder }\end{array}$} \\
\hline $\begin{array}{l}\text { The genesis of the } \\
\text { phenomenon }\end{array}$ & \multicolumn{2}{|l|}{ social risk response } \\
\hline $\begin{array}{l}\text { The nature of social } \\
\text { contradictions }\end{array}$ & $\begin{array}{l}\text { the conflict of interests of the opposing parties bas } \\
\text { contradictions of their habitus }\end{array}$ & $\begin{array}{l}\text { ed on the } \\
\text { limiting the viability } \\
\text { of society/individual } \\
\text { social groups }\end{array}$ \\
\hline Value orientations & $\begin{array}{l}\text { instrumental } \\
\text { groups at risk - deviants by nature }\end{array}$ & terminal \\
\hline Subjects & $\begin{array}{l}\text { childhood and youth (as a spiritual degeneration } \\
\text { of the future basis of society) }\end{array}$ & \\
\hline $\begin{array}{l}\text { The social image of the } \\
\text { subject }\end{array}$ & $\begin{array}{l}\text { violator of public order, } \\
\text { a culprit of social ills }\end{array}$ & \\
\hline Objects & $\begin{array}{l}\text { children and youth (in case of the mass nature of } \\
\text { the phenomenon, the purposefulness of the } \\
\text { process of their extermination) }\end{array}$ & $\begin{array}{l}\text { the whole } \\
\text { society/individual } \\
\text { social groups }\end{array}$ \\
\hline $\begin{array}{l}\text { The social image of the } \\
\text { object }\end{array}$ & hostage to circumstances, a victim of social injusti & \\
\hline Agents & Mass media, authorized experts, the political elite & \\
\hline $\begin{array}{l}\text { Technology } \\
\text { Social reactions of society }\end{array}$ & $\begin{array}{l}\text { emotive moralizing-discourse } \\
\text { the stigmatization of the culprit, repressive and p } \\
\text { against the violator, readiness for crusades }\end{array}$ & nitive measures \\
\hline Actions of the society & affective & $\begin{array}{l}\text { value-rational, goal- } \\
\text { oriented }\end{array}$ \\
\hline Social changes & $\begin{array}{l}\text { breaking ties with individual communities, provol } \\
\text { consolidation of society, rethinking of existing nor }\end{array}$ & $\begin{array}{l}\text { ing affective reactions; } \\
\text { ms and values }\end{array}$ \\
\hline Approaches used & activity-based, theory of social construction of rea & ity, structuralist \\
\hline
\end{tabular}


Both types of moral panic have a lot in common. Their purpose is to build a social conflict that leads to mutually beneficial social changes: on the one hand, ties with individual communities are breaking, causing negative reactions in the social environment, on the other - against the background of consolidation of social catastrophe occurs, rethinking of existing norms that are perceived and valued when people begin to revise social boundaries. However, when social change is fully polarised, the constructive and destructive consequences of moral panic are mutually conditioned since they can be isolated. In general, quarantine during a pandemic and social unrest is a clear deterioration in the quality of life. As a result, all loss reactions are natural for a person modeled after the American psychologist and psychotherapist Kubler Ross (2001). She found that most people with serious problems experience the same range of emotions, go through similar stages to accept the problem and, most importantly, try to create the illusion of a safe world around them. When Kubler-Ross (2015), observed people who, for example, experienced suffering, recently lost a loved one, or had an incurable disease, she said that absolutely everyone underwent the same phases of psychological reaction to the problem: rejection, panic, anger, depression, dailiness.

The first reaction of people who knew about COVID-19 and the possibility of dying from this disease was shocking. The coronavirus is developing according to E. Kubler Ross' paradigm, who passed this stage very quickly. Then the rejection phase began: There is no coronavirus! Many people wanted and still want to believe this. For example, during the COVID-19 quarantine period, the rejection was reflected in the fact that every fourth person in Russia became a dissident (this is not a new phenomenon, for example, during the Spanish flu). In 1918, there were competitions against masks, and every second man was either not afraid of getting sick, or was sure that he was not. The virus was not in danger (Bloem \& Salemi, 2021). In this situation, simple and clear recommendations, such as washing hands as often as possible, seem unconvincing and insufficient, as they occur too often. For the same reasons, they quickly devalued, as a result of which many were already ignored at the rejection stage. At the next stage, the psyche reacts differently to events. Research data on the Internet shows that the disease is often perceived as a threat that has become a problem for the whole of mankind and a pandemic that needs to be fought (44\%) and recognizes the epidemic as a biological weapon (39\%). They consider this a planned step for the political and economic elite of each country (32\%) (Stepantsov \& Vileikis, 2020). Regardless of where the threat came from. More important here was the combination of an ultimatum, extraordinary situations, and paramilitary events.

In the phase of panic anger, the increase in anxiety was already indicative, especially in a situation where a person was ill; fear; acute stress disorder, which is three times more common; insomnia; increased fatigue and poor concentration; irritability and anger, indecisiveness, anger directed at those who, for example, did not take precautions: went to other countries and infected other people (Brewer, 2019). Such behavioral responses can fairly be considered as an evolving defense mechanism, a process of physiological activation, or an unconsciously triggered emotion. When trying to interpret the situation as a potential threat, a person felt a fight-or-flight response (Robson, 2020). With the current quarantine on COVID-19, people are still under pressure from the information environment. Notably, the abundance of negative information leads to increased anxiety and hurts the mental health of a person. The Internet, TV news, word of mouth - everything makes people think about the threat. As a result, a person is more likely to experience anxiety and depression in addition to the problems that he has already experienced.

A constant sense of danger can have more serious consequences for the human psyche. Because of a deeply developed reaction to the fear of illness, a person becomes more tribalistic, his moral judgments become stricter, and his social attitudes become more conservative. It has been found that daily reminders of the pandemic can undermine people's political beliefs. As a rule, the defensive state of mind is replaced by a provocative mood. Feelings of anxiety and depression pass away, and the person begins to adapt to the changes more effectively (de Pablo et al., 2020; Tang et al., 2020). Thus, the longer the epidemic lasts, the lower is the level of concern. This is mainly because the duration of this process increases the awareness of its participants about the disease. The phase of dailiness begins. For a person, everything remains understandable and predictable. As a result, he may again stop taking the necessary safety measures. Due to this, the second wave of coronavirus has become inevitable in many countries. Anxiety is undoubtedly one of the most important factors affecting a person's psychological and somatic health in the context of COVID-19.

Tolmacheva, S., Tkachev, A., \& Shamshin, M. (2021). The impact of the pandemic on moral panics in society. International Journal of Health Sciences, 5(3), 232-243. https://doi.org/10.53730/ijhs.v5n3.1485 
There are many reasons to worry about the pandemic. According to psychologists and psychiatrists, it is mainly:

1) the ambiguity of the situation, which causes it to be interpreted in different ways. This happens when a new disease appears, the characteristics and consequences of which are unknown.

2) uncertainty, unpredictability. It is not yet clear how the spread of COVID-19 will develop and what the global consequences of the pandemic will be.

It is safe to say that the introduction of quarantine and self-isolation has a detrimental effect on the mental health of a person. The question of what is worse remains the harmful effects of quarantine or the impact of the infection itself on physical health (Maugeri et al., 2020; Lima et al., 2020). The efforts of psychiatrists and psychologists are now primarily focused on studying the possible negative effects of quarantine on the psyche (Figure 1).

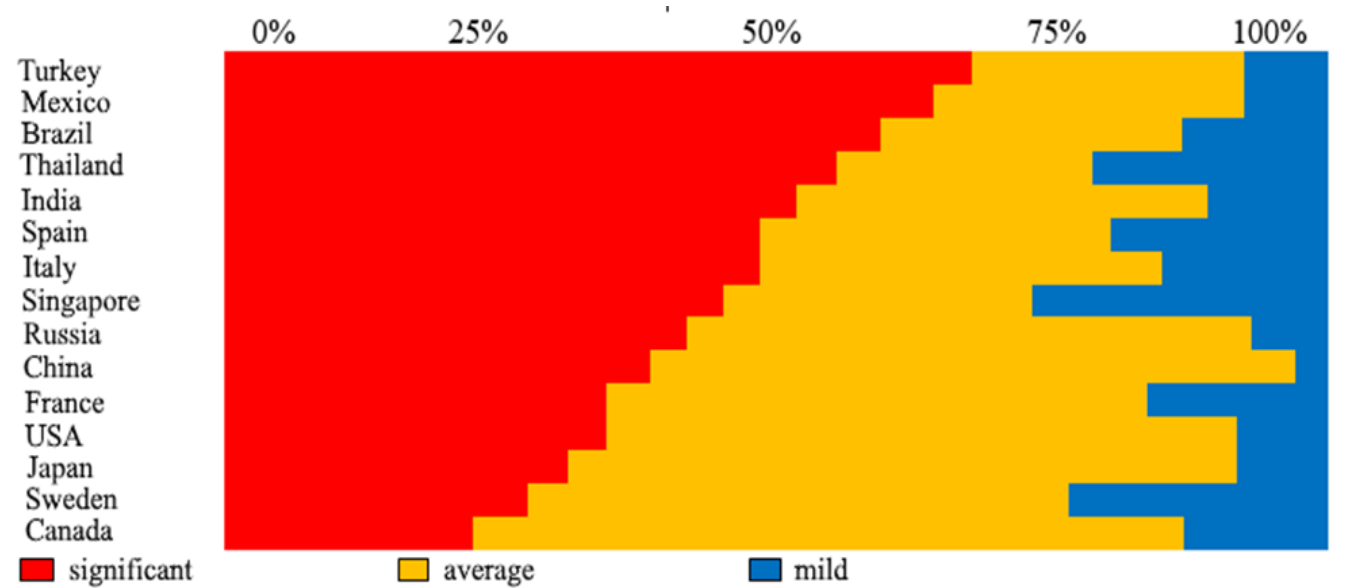

Figure 1. The impact of the pandemic on moral panic in different countries

During a pandemic, a person needs to be able to distinguish between normal and phobic anxiety. The main difference is that healthy anxiety helps to solve problems, while excessive and painful anxiety interrupts the performance of work and life and leads to demoralization and mental exhaustion. Statistics show that up to $33.7 \%$ of the world's population suffers from some form of anxiety at some point in their lives. Now is the time when the risk of being left alone with anxiety is low: for example, in China, where the COVID-19 epidemic broke out, $28.8 \%$ of people experienced moderate to severe stress and $8.1 \%$ experienced severe stress (Schaller et al., 2015). In the context of the pandemic, coronavirus has become almost the only medical concern for many people. According to monitoring conducted in Russia at the end of $2020,60 \%$ of respondents considered COVID-19 a threat. At the same time, 54\% were afraid of AIDS, 50\% of respondents were afraid of cardiovascular diseases, and $39 \%$ of tuberculosis. Only oncology has not given way to the coronavirus. Of those who responded to the online survey, $83 \%$ were still afraid of getting cancer (Roy et al., 2020; Nicomedes \& Avila, 2020). As a result, according to experts, the main belief of a person in his own symbolic experience of insecurity and immortality was under psychological shock; to believe in the stability of the world, its predictability; it was the realization of the fullness of human potential (Taylor, 2019). It is noteworthy that people have returned to one of their basic needs. According to Maslow's pyramid, it is somatic health. According to the IT company OFD Platform, as a result of the first 10 months of 2020, Russians spent more on medicines, food, recreation, and fitness in huge categories of goods. The average expenditure tax increased by an average of $21.5 \%$. According to experts, in the future, people will care more about their health and the health of their loved ones than before.

Panic has become a factor that negatively affects human health in the context of a pandemic. For example, neuropsychologist and psychiatrist J. Brewer believes that this sudden emotion generates fear - the oldest survival mechanism (Li et al., 2020). The intensity of this response depends on the function of the brain, 
namely the amygdala, which is responsible for emotions, caution, and fear, and the frontal cortex, which helps a person plan for the future and make decisions. When a threat arises, the amygdala asks the person to respond to the danger and triggers a fight-or-flight response. This activates the process of predicting events, and if there is not enough information, stress is triggered in response to this panic attack. This further suppresses the psyche and negatively affects the process of making important decisions (Ylldırım et al., 2020). In the future, the need for additional information is becoming more urgent, and the Internet is the most accessible source in modern conditions.

However, there is still too much false information on the Internet that is difficult to discern. Rumors of panic spread like lightning, which not only confuses a person but also causes direct psychological damage, not allowing him to take measures to prevent an aggravation of the situation. And when a person's fear gets out of control, fakes not only cause immediate panic but also create a pandemic of fear. According to Professor Jacek Debi (Institute of Molecular and Behavioural Neuroscience, University of Michigan), this leads to panic, which quickly passes from a single form of manifestation to a mass one. This phenomenon of social infection was described by a doctor and sociologist at Yale University, Professor N. Christakis in his book "Apollo's arrow: the deep and lasting impact of the coronavirus on our way of life" (Christakis, 2020). Examples of this infection can be found, for example, during major events. It is known that in the history of mankind, mass panic often ended tragically.

The fear of infection cannot be prevented, it happens automatically, but psychologists say that its consequences can be reduced. Since this is a social phenomenon, the classical rules of social behavior are applied to reduce the level of anxiety. For example, the research of psychologists J.R. Bloem, C. Salemi has shown that the fear of re-infection decreases in the presence of a calm and confident person (Bloem \& Salemi, 2021). In a large society, the government should play the role of such an authoritarian figure. But it is unproductive, for example, to calm down listening to stories where people in protective suits are testing the virus and there is no need to panic. This, of course, increases the concerns. According to experts, information about dangers and safety should be accompanied by clear instructions, because it is difficult for people experiencing stress to understand the details and nuances (Averyanova, 2020; Widana et al., 2021). Another common type of panic attack during a pandemic is stupor - a condition in which a person does not deny the danger, but does not defend himself. Out of stupor and disbelief in his abilities, he simply says: Everything is wrong, we will die - and usually goes to the crowded car. No one likes coincidences and uncertainty. Consequently, the panic at the beginning of the pandemic increased distrust of social institutions and the spread of conspiracy theories that urge not to trust the official source of information because they are to blame for everything or hide information because it helps them. Oddly enough, it gave people a sense of greater control over the situation. Because of distrust at the beginning of their isolation, people lost what they needed: real information about what was happening and practical recommendations that could help relieve excessive mental stress and preserve their health (Nishiura et al., 2020; Luo et al., 2020).

\section{Conclusion}

The events of the first months of 2020 undoubtedly hurt the life of people, their self-confidence, and vitality. In general, the experts assessed the well-being of people in Russia and abroad and concluded that there is currently no mental pandemic. But the pandemic contributes to the manifestation of destructive mental reactions in healthy people, including phobias, obsessions, and distorted perception of the real situation. At the same time, the artificial fear that occurs during a pandemic improves thinking and reduces the risk of long-term evaluation of government actions. However, the way out of the crisis depends on the person himself, as in the case of drowning, because the feeling of a pandemic depends on the picture of the world in his head. Various studies conducted in Europe, America, and Asia during the first wave of the epidemic show that social isolation should be considered as one of the most important factors negatively affecting the mental health of most people. Discrimination has been introduced in many countries around the world to reduce the burden on the health system. Forced isolation, loss of relationships with many people caused many psychological problems, including loneliness, depression, fear, apathy. Specialists noted that after the collapse, several symptoms developed. Falling and declining incomes due to COVID-19 have also inevitably led to

Tolmacheva, S., Tkachev, A., \& Shamshin, M. (2021). The impact of the pandemic on moral panics in society. International Journal of Health Sciences, 5(3), 232-243. https://doi.org/10.53730/ijhs.v5n3.1485 
higher levels of anxiety, lower self-esteem in a significant number of people, and, as a result, higher drug use and an increase in suicide.

Self-doubt and sense of insecurity of the future, anxiety during the period of uncertainty, which is the moment of the spread of a new coronavirus, causes emotional exhaustion, weakens the immune system, which, in turn, negatively affects the human nervous system, leads to an exacerbation of chronic diseases. It has been found that a fear of COVID-19 and panic over negative news can cause other physical problems. The long-term psychological impact of the pandemic is not yet clear, but preliminary research suggests that depression, stress disorders, and drug addiction may increase shortly. Based on the sociological analysis, the author defines the concept of moral panic, which is a process of cyclical social changes that occur as a result of people's affective reaction to a series of interrelated phenomena united by a common or similar problem, for example, the threat of destruction of longstanding moral norms and spiritual values. Moral panic refers to a social process that is not always subject to external regulation and control, often on a mass and spontaneous basis. Acting as a factor of social change, moral panic transforms the system of moral norms, spiritual values, and the world perceives people taking into account modern realities.

\section{Acknowledgments}

We are grateful to two anonymous reviewers for their valuable comments on the earlier version of this paper. 


\section{References}

American Psychoanalytic Association. (2018). Psychoanalytic terms and concepts. Yale University Press.

Arseniev, K.K., \& Petrushevsky, F.F. (1897). Encyclopedic dictionary of F.A. Brockhaus and I.A. Efron. Saint Petersburg: Semenovskaya Tipolitografiya.

Averyanova, 0. (2020). Scientists have found that for a person loneliness is equivalent to hunger.

Bloem, J. R., \& Salemi, C. (2021). COVID-19 and Conflict. World development, 140, 105294.

Bocharova, 0.A. (2018). From multicultural society to intercultural education. Bulletin of Mukachevo State University. Series "Pedagogy and Psychology", 2(8), 17-21.

Brewer, J. (2019). Addicted brain. Moscow: Mann, Ivanov and Ferber.

Brooks, S. K., Webster, R. K., Smith, L. E., Woodland, L., Wessely, S., Greenberg, N., \& Rubin, G. J. (2020). The psychological impact of quarantine and how to reduce it: rapid review of the evidence. The lancet, 395(10227), 912-920. https://doi.org/10.1016/S0140-6736(20)30460-8

Cherepania, N.I., \& Rusyn, N.M. (2018). Psychological and pedagogical conditions of development of moral position of pre-school teacher in the process of self-education. Bulletin of Mukachevo State University. Series "Pedagogy and Psychology", 1(7), 129-133.

Chernychko, T. V., \& Ihnatyshyn, M. V. (2020). Analysis of Economic Support Measures in the Conditions of the COVID-19 Pandemic. Scientific Bulletin of Mukachevo State University. Series "Economy, 1(13), 67-72.

Christakis, N. A. (2020). Apollo's Arrow: The Profound and Enduring Impact of Coronavirus on the Way We Live. Little, Brown Spark.

de Pablo, G. S., Vaquerizo-Serrano, J., Catalan, A., Arango, C., Moreno, C., Ferre, F., ... \& Fusar-Poli, P. (2020). Impact of coronavirus syndromes on physical and mental health of health care workers: Systematic review and meta-analysis. Journal of affective disorders, 275, 48-57. https://doi.org/10.1016/j.jad.2020.06.022

Fedosenko, E. V. (2020). Zhizn'posle karantina: psihologija smyslov i koronavirus COVID-19 [Life after quarantine: the psychology of meanings and the coronavirus COVID-19]. Psihologicheskie problemy smysla zhizni i acme, 25, 34-47.

Goghari, V. M., Hagstrom, S., Madon, S., \& Messer-Engel, K. (2020). Experiences and learnings from professional psychology training partners during the COVID-19 pandemic: Impacts, challenges, and opportunities. Canadian Psychology/Psychologie Canadienne, 61(3), 167.

Gudzhiyev, G.I. (2012). Views from the real world. Moscow: Enigma.

Honcharenko, O. V., \& Polianychko, A. O. (2020). On the Content of the Medico-Social Component of Training Social Workers to Work. Scientific Bulletin of Mukachevo State University. Series "Pedagogy and Psychology, 1(11), 63-66.

Hussin, D. A., Samah, M. A. A., Suhaimi, A. A., \& Kamarudin, M. K. A. (2021). A study on knowledge, attitude and practice of COVID-19 pandemic among the residents. International Journal of Health Sciences, 5(2), 177 188.

Ivanova, T. Y., Leontiev, D. A., \& Rasskazova, E. I. (2016). Functions of Personality Resources in a Situation of Economic Crisis. Psychology-Journal of the Higher School of Economics, 13(2), 323-346.

Kierkegaard, S. (2010). Fear and awe. Moscow: Kulturnaya revolyutsiya.

Kubler-Ross, E. (2015). Conceptual Frameworks Guiding Death \& Dying. Nursing Care at the End of Life, 25.

Kuzmenko, O.V., Kashcha, M.O., \& Marchenko, R.V. (2021). Structural modelling of the relationship between the vulnerability of Ukrainian regions to COVID-19, environmental status and factors of readiness of the medical system. Scientific Bulletin of Mukachevo State University. Series “Economics", 8(2), 123-130.

Li, S., Wang, Y., Xue, J., Zhao, N., \& Zhu, T. (2020). The impact of COVID-19 epidemic declaration on psychological consequences: a study on active Weibo users. International journal of environmental research and public health, 17(6), 2032.

Lima, C. K. T., de Medeiros Carvalho, P. M., Lima, I. D. A. A. S., de Oliveira Nunes, J. V. A., Saraiva, J. S., de Souza, R. I., ... \& Neto, M. L. R. (2020). The emotional impact of Coronavirus 2019-nCoV (new Coronavirus disease). Psychiatry research, 287, 112915. https://doi.org/10.1016/j.psychres.2020.112915

Loades, M. E., Chatburn, E., Higson-Sweeney, N., Reynolds, S., Shafran, R., Brigden, A., ... \& Crawley, E. (2020). Rapid systematic review: the impact of social isolation and loneliness on the mental health of children and adolescents in the context of COVID-19. Journal of the American Academy of Child \& Adolescent Psychiatry, 59(11), 1218-1239. https://doi.org/10.1016/j.jaac.2020.05.009

Tolmacheva, S., Tkachev, A., \& Shamshin, M. (2021). The impact of the pandemic on moral panics in society. International Journal of Health Sciences, 5(3), 232-243. https://doi.org/10.53730/ijhs.v5n3.1485 
Luo, M., Guo, L., Yu, M., Jiang, W., \& Wang, H. (2020). The psychological and mental impact of coronavirus disease 2019 (COVID-19) on medical staff and general public-A systematic review and metaanalysis. Psychiatry research, 291, 113190. https://doi.org/10.1016/j.psychres.2020.113190

Maddi, S. (2017). Formation of meaning in the decision-making process. Psychological journal, 26(6), 87-101.

Maddi, S. R., \& Khoshaba, D. M. (1994). Hardiness and mental health. Journal of personality Assessment, 63(2), 265-274.

Makovetska, I.H. (2020). Features of distance vocal training in the COVID-19 pandemic: Psychological and pedagogical aspects. Scientific Bulletin of Mukachevo State University. Series "Pedagogy and Psychology", 6(2), 50-58.

Mamardashvili, M. K. (1968). Forms and content of thinking. Middle High school, 6.

Maugeri, G., Castrogiovanni, P., Battaglia, G., Pippi, R., D'Agata, V., Palma, A., ... \& Musumeci, G. (2020). The impact of physical activity on psychological health during Covid-19 pandemic in Italy. Heliyon, 6(6), e04315. https://doi.org/10.1016/j.heliyon.2020.e04315

Nicomedes, C. J. C., \& Avila, R. M. A. (2020). An analysis on the panic during COVID-19 pandemic through an online form. Journal of affective disorders, 276, 14-22. https://doi.org/10.1016/j.jad.2020.06.046

Ningsih, S., Ismail, D., \& Indriani, I. (2021). Study protocol: relationship between parenting patterns and diet with nutritional status of toddlers during COVID-19 pandemic. International Journal of Health Sciences, 5(2), 128-134.

Nishiura, H., Linton, N. M., \& Akhmetzhanov, A. R. (2020). Serial interval of novel coronavirus (COVID-19) infections. International journal of infectious diseases, 93, 284-286. https://doi.org/10.1016/j.ijid.2020.02.060

Ozhegov, S. I., \& Shvedova, N. Y. (2018). Russian Language Interpretation Dictionary. Retrieved March, 8.

Prus, L. R. (2021). Customs management: preservation of international supply chains and implementation of customs policy to counter the crisis COVID-19.

Robson, D. (2020). The fear of coronavirus is changing our psychology. BBC Future. Retrieved September, 9 , 2020.

Roy, D., Tripathy, S., Kar, S. K., Sharma, N., Verma, S. K., \& Kaushal, V. (2020). Study of knowledge, attitude, anxiety \& perceived mental healthcare need in Indian population during COVID-19 pandemic. Asian journal of psychiatry, 51, 102083. https://doi.org/10.1016/j.ajp.2020.102083

Schaller, M., Murray, D. R., \& Bangerter, A. (2015). Implications of the behavioural immune system for social behaviour and human health in the modern world. Philosophical Transactions of the Royal Society B: Biological Sciences, 370(1669), 20140105.

Selye, H. (1960). Essays on adaptation syndrome. Moscow: Medgiz.

Shatska, Z.Y. (2021). Enterprise integration models: Advantages and challenges of implementation in the context of the COVID-19 pandemic. Scientific Bulletin of Mukachevo State University. Series "Economics", $8(2), 17-24$.

Stepantsov, P., \& Vileikis, A. (2020). Coronavirus and society. How Russians are responding to the epidemic.

Tang, B., Xia, F., Tang, S., Bragazzi, N. L., Li, Q., Sun, X., ... \& Wu, J. (2020). The effectiveness of quarantine and isolation determine the trend of the COVID-19 epidemics in the final phase of the current outbreak in China. International Journal of Infectious Diseases, 95, 288-293. https://doi.org/10.1016/j.ijid.2020.03.018

Taylor, S. (2019). The psychology of pandemics: Preparing for the next global outbreak of infectious disease. Cambridge Scholars Publishing.

Tillikh, P., \& Sedakova, O. (1995). Muzhestvo byt'[The courage to be]. Tillikh P. Izbrannoye. M, 7-131.

van Dyck, L. I., Wilkins, K. M., Ouellet, J., Ouellet, G. M., \& Conroy, M. L. (2020). Combating heightened social isolation of nursing home elders: the telephone outreach in the COVID-19 outbreak program. The American journal of geriatric psychiatry, 28(9), 989-992. https://doi.org/10.1016/j.jagp.2020.05.026

Van Hoof, E. (2020, April). Lockdown is the world's biggest psychological experiment-and we will pay the price. In World Economic Forum (Vol. 9).

Vinarchuk, N.M., Haliuka, O.S., \& Sholovii, M.-T.I. (2021). Features of using health-saving and IC-technologies in the formation of a socially mobile teacher in a pandemic condition. Scientific Bulletin of Mukachevo State University. Series "Pedagogy and Psychology", 7(2), 70-78. 
Widana, I.K., Sumetri, N.W., Sutapa, I.K., Suryasa, W. (2021). Anthropometric measures for better cardiovascular and musculoskeletal health. Computer Applications in Engineering Education, 29(3), 550561. https://doi.org/10.1002/cae.22202

Yıldırım, M., Arslan, G., \& Özaslan, A. (2020). Perceived risk and mental health problems among healthcare professionals during COVID-19 pandemic: exploring the mediating effects of resilience and coronavirus fear. International Journal of Mental Health and Addiction, 1-11.

Zanon, C., Dellazzana-Zanon, LL, Wechsler, SM, Fabretti, RR, \& Rocha, KND (2020). COVID-19: implications and applications of Positive Psychology in times of pandemic. Psychology Studies (Campinas), 37.

\section{Biography of Authors}

\begin{tabular}{|l|l|}
\hline Svetlana Tolmacheva - Full Doctor in Sociology, Professor at the Department of \\
Marketing and Public Administration, Industrial University of Tyumen, Tyumen, \\
Russian Federation. \\
Email: tolmacheva6609-4@ust-hk.com.cn
\end{tabular}

Tolmacheva, S., Tkachev, A., \& Shamshin, M. (2021). The impact of the pandemic on moral panics in society. International Journal of Health Sciences, 5(3), 232-243. https://doi.org/10.53730/ijhs.v5n3.1485 